\title{
Synthesis of $\boldsymbol{m}$-Bromophenol- ${ }^{14} \mathrm{C}_{6}$ with High Specific Activity ${ }^{\dagger}$
}

\author{
Takashi MoRIYA, Terutomi Mogi and Hiromitsu MATSUOKA \\ Division of Radioisotope Production, Radioisotope Center, \\ Japan Atomic Energy Research Institute \\ Tokai-mura, Naka-gun, Ibaraki-ken 319-11 \\ Received February 1, 1978
}

\section{Introduction}

$m$-Bromophenol-14 $\mathrm{C}_{6}$ with high specific activity of ca. $20 \mathrm{mCi} / \mathrm{mmol}$ has been required as the intermediate for labeling O,O-dimethyl-O(3-methyl-4-nitrophenyl) phosphorothioate; $\mathrm{Su}$ mithion, a famous insecticide.

We previously prepared this phenol with specific activity of $6.5 \mathrm{mCi} / \mathrm{mmol}$ on $15 \mathrm{mmol}$ scale. The synthesis involved the conversion of benzene- ${ }^{-14} \mathrm{C}_{6}$ with the mixture of nitric acid and sulfuric acid, bromination of the nitrobenzene ${ }^{14} \mathrm{C}_{6}$ with bromine in the presence of iron powder ${ }^{1)}$, reduction of $m$-bromonitrobenzene- ${ }^{14} \mathbf{C}_{6}$ to $m$-bromoaniline- ${ }^{14} \mathbf{C}_{6}$ with tin and hydrochloric acid ${ }^{2)}$ and hydrolysis of the diazotized $m$-bromoaniline- ${ }^{14} \mathrm{C}_{6}$ to form $m$-bromophenol-14 $\mathrm{C}_{6}{ }^{3}$. Yoshitake, et al. prepared ringlabeled Sumithion using this $m$-bromophenol-14 $\mathrm{C}_{6}{ }^{4}$.

In our previous work, every stage except the bromination step resulted satisfactory. We encountered difficulty in isolation of $m$-bromonitrobenzene $-{ }^{14} \mathrm{C}_{6}$ from the reaction mixture after completion of the bromination reaction. Repetition of fractional distillation using non-radioactive nitrobenzene as a carrier was required to remove the unreacted nitrobenzene-1 ${ }^{14} \mathrm{C}_{6}$, which lowered yield.

Since the present work necessitated smaller scale synthesis, the previous method became of less value. Therefore, special emphasis was laid on establishing an alternative method

†高比放射能 $m$-ブロモフェノール ${ }^{14} \mathrm{C}_{6}$ の合成. 守屋 孝, 茂木照十三, 松岡弘充 : 日本原子力研究所東 海研究所ラジオアイソトープ事業部製造部, 31911 茨城県那珂郡東海村 for the preparation of $m$-bromonitrobenzene- ${ }^{-14} \mathrm{C}_{6}$ on the scale we wished to achieve. Ponoomarenko reported the substitution reaction between the nitro groups in $m$-dinitrobenzene and chlorine derived from carbon tetrachloride on heating at $270-290^{\circ}$ in a sealed tube ${ }^{5}$. We found that bromination also took place with the use of carbon tetrabromide instead of carbon tetrachloride. Monosubstituted product was obtained when the reaction was carried out under moderate conditions $\left(270^{\circ}, 60-80\right.$ minutes). Although this method represents the disadvantage of converting only ca. $35 \%$ of $m$-dinitrobenzene to $m$-bromonitrobenzene, the result seemed satisfactory because of the following reasons:

(1) Separation of $\mathrm{m}$-bromonitrobenzene from the reaction mixture can easily be achieved by column chromatography.

(2) About $50 \%$ of $m$-dinitrobenzene remains unreacted and can be recovered. Therefore, reutilization of this material affords an additional yield.

(3) $m$-Dinitrobenzene- ${ }^{-14} \mathrm{C}_{6}$ can be prepared in a single step from benzene- ${ }^{14} \mathrm{C}_{6}$ in good yield ${ }^{6}$. This compound is easier to handle and less hazardous owing to its non-volatile property.

The ratio of the composition in the reaction products varied depending on the reaction conditions: when the reaction was carried out at higher temperature, the ratio of $m$-dibromobenzene increased, whereas that of $m$-bromonitrobenzene did only slightly, with decrease of that of $m$-dinitrobenzene.

Eventually, $50 \mathrm{mCi}$ of $m$-bromophenol-14 $\mathrm{C}_{6}$ with specific activity of $23.5 \mathrm{mCi} / \mathrm{mmol}$ was 
prepared from $205 \mathrm{mCi}$ of benzene- ${ }^{-14} \mathrm{C}_{6}$ according to the synthetic scheme as shown in Figure 1. Purity of the product at each stage was determined both chemically and radiochemically by radiogaschromatography. Confirmation of the identities was accomplished by comparison of the retention times with those of the authentic samples.

\section{Experimental}

$2 \cdot 1 m$-Dinitrobenzene- ${ }^{-14} \mathrm{C}_{6} \quad$ Benzene- ${ }^{-14} \mathrm{C}_{6} \quad$ (6.1 mmol, $205 \mathrm{mCi}$ ) was converted to $m$-dinitrobenzene- ${ }^{14} \mathrm{C}_{6}$ of such a way as described in the preceeding paper ${ }^{6}$. The product thus obtained was recrystallized from $90 \%$ ethanol to remove a small amount of $o$-isomer. The yield was $758 \mathrm{mg}(149 \mathrm{mCi}, 33.0 \mathrm{mCi} / \mathrm{mmol} ; 73 \%)$.

$2.2 m$-Bromonitrobenzene- ${ }^{-14} \mathrm{C}_{6} \quad m$-Dinitrobenzene ${ }^{-14} \mathrm{C}_{6}(1.5 \mathrm{mmol}, 50 \mathrm{mCi})$ and $\mathrm{CBr}_{4}(0.75$ $\mathrm{mmol})$ were sealed in a Pyrex tube $(12 \times 150$ $\mathrm{mm}$ ) and heated in an electric furnace at $270^{\circ}$ for $80 \mathrm{~min}$. The contents of the tube were then chilled with liquid nitrogen and the tube was opened in a vacuum line. After the volatile substances had been removed under reduced pressure (ca. 100 Torr), the tube was detached from the vacuum line and a small amount of $n$-hexane was added to the residue. The solution was poured onto a column of silica gel (Merck, 70-230 mesh, $12 \times 150 \mathrm{~mm}$ ) and elution was made first with $50 \mathrm{~m} l$ of $n$-hexane, then with $100 \mathrm{~m} l$ of $95 \% n$-hexane/ether and finally with $100 \mathrm{~m} l$ of $85 \% n$-hexane/ether. The unreacted $m$-dinitrobenzene- ${ }^{14} \mathrm{C}_{6}$ which was eluted in the third fraction and remained insoluble in $n$-hexane was recovered by recrystallization after evaporation of the eluent. In this procedure, an appropriate amount of pure $\mathrm{m}^{-}$ dinitrobenzene was employed as a carrier to aid recovery of the labeled material. The recovered $m$-dinitrobenzene- ${ }^{-14} \mathrm{C}_{6}$ was subjected to the same reaction. The result of six runs including reutilization of the recovered material is summarized in Table 1. The second fractions from each run which contained radiochemically pure $m$-bromonitrobenzene- ${ }^{-14} C_{6}$ were combined and evaporation of the eluent gave the desired product. The yield was $690 \mathrm{mg}(82.5 \mathrm{mCi}$, $24.1 \mathrm{mCi} / \mathrm{mmol}$; 55\%).<smiles>Cc1cccc([N+](=O)[O-])c1</smiles>

Fig. 1 Synthetic scheme for the preparation of $m$-bromophenol- ${ }^{14} \mathrm{C}_{6}$.

Table 1 The result of the synthesis of $m$-bromonitrobenzene ${ }^{-14} \mathrm{C}_{6}$.

The bromination products separeted by column

chromatography on silica gel with three kinds of eluents

\begin{tabular}{|c|c|c|c|c|c|c|c|c|c|c|}
\hline & \multirow{2}{*}{$\begin{array}{l}\text { Starting } \\
\text { material } \\
\mathrm{mg}\end{array}$} & \multirow{2}{*}{$\mathrm{mCi}$} & \multicolumn{8}{|c|}{ Products } \\
\hline & & & \multicolumn{2}{|c|}{$\begin{array}{c}\text { Fraction } 1^{\mathrm{a}} \\
m \text {-dibromobenzene } \\
\mathrm{mCi} \% \text { oyield }\end{array}$} & \multicolumn{2}{|c|}{$\begin{array}{c}\text { Fraction } 2 \\
m \text {-bromonitrobenzene } \\
\mathrm{mCi} \quad \text { \%yield }\end{array}$} & \multicolumn{2}{|c|}{$\begin{array}{c}\text { Fraction } 3 \\
m \text {-dinitrobenzene } \\
\mathrm{mCi} \% \text { yield }\end{array}$} & \multicolumn{2}{|c|}{$\begin{array}{c}\text { Residue }{ }^{\mathrm{b}} \\
\text { m-dinitrobenzene } \\
\mathrm{mCi} \text { \%yield }\end{array}$} \\
\hline 1. & 254 & 49.8 & 8.0 & 16.1 & 18.5 & 37.1 & 7. 2 & 14.4 & 15.6 & 31.3 \\
\hline 2. & 248 & 48.7 & 6.2 & 12.7 & 17.3 & 35.5 & 8.0 & 16.4 & 14.8 & 30.4 \\
\hline 3. & 247 & 48.5 & 5.5 & 11.3 & 15.6 & 32.2 & 6.8 & 14.0 & 20.5 & 42.2 \\
\hline 4. & $244^{\mathrm{c}}$ & 32.0 & 7.0 & 21.8 & 12.6 & 39.4 & 5.0 & 15. 6 & 8.2 & 25.6 \\
\hline 5. & $240^{c}$ & 31.4 & 6.1 & 19.4 & 10.0 & 31.8 & 5.5 & 17.5 & 8.8 & 28.0 \\
\hline 6. & $281^{\mathrm{d}}$ & 22.0 & 6.0 & 27.3 & 9.2 & 41.8 & 2.6 & 11.8 & $\cdots$ & $\cdots$ \\
\hline
\end{tabular}
a. also contained a slight amount of tri- and tetrabromobenzenes.
b. also contained a small amount of $m$-bromonitrobenzene.
c. recovered from fraction 3 and residue in exp. 1, 2 and 3 with the aid of $168 \mathrm{mg}$ carrier.
d. recovered from fraction 3 and residue in exp. 4 and 5 with the aid of $168 \mathrm{mg}$ carrier. 
$2 \cdot 3 m$-Bromoaniline- ${ }^{-14} \mathrm{C}_{6} \quad m$-Bromonitrobenzene- ${ }^{14} \mathrm{C}_{6}$ (698 $\left.\mathrm{mg}, 82.5 \mathrm{mCi}\right)$ was dissolved in 5 $\mathrm{m} l$ of warm ethanol/water $(3: 2 \mathrm{v} / \mathrm{v})$ in a flaskequipped with a reflux condenser. Granulated tin $(2 \mathrm{~g})$ was added and the solution was warmed at $50^{\circ}$ for a few min. Concentrated $\mathrm{HCl}$ $(6.5 \mathrm{~m} l)$ was added portionwise to the solution during $20 \mathrm{~min}$ and the solution was refluxed for $30 \mathrm{~min}$. Concentrated $\mathrm{NaOH}$ solution was then added to make the solution alkaline and the solution was extracted three times with ether. The combined ether solution was dried over $\mathrm{Na}_{2} \mathrm{SO}_{4}$ and concentrated to ca. $50 \mathrm{~m} l$. Dry $\mathrm{HCl}$ gas was then introduced into the ether solution and the precipitate of $m$-bromoaniline${ }^{14} \mathrm{C}_{6}$ hydrochloride formed was collected by filtration. The yield was $592 \mathrm{mg}(67.6 \mathrm{mCi}$, $23.8 \mathrm{mCi} / \mathrm{mmol}$; $82 \%$ ).

$2.4 m$-Bromophenol-14 $\mathrm{C}_{6} \quad m$-Bromoaniline- ${ }^{14} \mathrm{C}_{6}$ hydrochloride ( $592 \mathrm{mg}, 67.6 \mathrm{mCi}$ ) was dissolved in $12 \mathrm{ml}$ solution of conc $\mathrm{H}_{2} \mathrm{SO}_{4}$ and water ( $1: 5$ $\mathrm{v} / \mathrm{v})$. To the precipitate formed on cooling with ice at $0-5^{\circ}, \mathrm{NaNO}_{2}(210 \mathrm{mg})$ in $3 \mathrm{ml}$ of water was added dropwise during $15 \mathrm{~min}$ with stirring. Stirring was continued for another $15 \mathrm{~min}$ and then urea $(20 \mathrm{mg})$ in $3 \mathrm{ml}$ of water was added to the solution with stirring. The diazotized aniline solution was filtered into the solution of conc $\mathrm{H}_{2} \mathrm{SO}_{4}(5 \mathrm{ml})$ and water (40 $\mathrm{m} l$ ). Then the mixture was distilled with steam and $350 \mathrm{ml}$ of the distillate was collected. The distillate was saturated with $\mathrm{NaCl}$ and extracted three times with ether. The ether solution was dried over $\mathrm{Na}_{2} \mathrm{SO}_{4}$ and the solvent was evaporated to leave chemically and radiochemically pure $m$-bromophenol-14 $\mathrm{C}_{6}$. The yield was $370 \mathrm{mg}$ ( $50.2 \mathrm{mCi}, 23.5 \mathrm{mCi} / \mathrm{mmol}$; $74 \%$ ).

\section{References}

1) H. Gilman and H. Blatt: Organic Syntheses Col. Vol. 1, 2nd Ed. p. 123, John Wiley \& Sons, New York (1963)

2) A. Weissberger: Technique of Organic Chemistry Vol. 6, Micro and Semimicro Methods, p. 335, Interscience, New York (1954)

3) A. Rieker, K. Scheffler and E. Muller: Liebigs Annal. Chem., 670, 23 (1963)

4) A. Yoshitake, K. Kawamura, T. Kamada and M. Endo: J. Labelled Compounds and Radiopharmaceuticals, 13, (3) 323 (1977)

5) A.A. Ponoomarenko: Zh. Obshch. Khim., 32, 4035 (1963); Chem. Abstr., 58, 13744g (1963)

6) T. Moriya: J. Labelled Compounds and Radiopharmaceuticals, in press. 